\title{
REVIEWS
}

Mateusz MaciejCzyk ${ }^{1, \text { A-D, F }}$, Agnieszka Pietrzykowska ${ }^{1, A-D, ~ F, ~}$ Anna Zalewska ${ }^{2,}$ A, B, E, F, MaŁgorzata Knaśs ${ }^{3,}$ A, B, F, Irena Daniszewska ${ }^{4}$, A, B

\section{The Significance of Matrix Metalloproteinases in Oral Diseases}

${ }^{1}$ Students' Scientific Group “Stomatological Biochemistry”, Department of Conservative Dentistry, Medical University of Bialystok, Poland

2 Department of Conservative Dentistry, Medical University of Bialystok, Poland

${ }^{3}$ Institute of Health Care, Higher Vocational School, Suwałki, Poland

${ }^{4}$ Specialist Dental Practice, Białystok, Poland

A - research concept and design; B - collection and/or assembly of data; C - data analysis and interpretation;

D - writing the article; $\mathbf{E}$ - critical revision of the article; $\mathbf{F}$ - final approval of article

\begin{abstract}
Matrix metalloproteinases (MMPs) belong to a family of structurally related zinc-dependent proteolytic enzymes that are known to play a key role in the catabolic turnover of extracellular matrix (ECM) components. Research studies to date have indicated that MMPs regulate the activity of several non-ECM bioactive substrates, including growth factors, cytokines, chemokines and cell receptors, which determine the tissue microenvironment. Disruption of the balance between the concentration of active matalloproteinases and their inhibitors (TIMPs) may lead to pathological changes associated with uncontrolled ECM turnover, tissue remodeling, inflammatory response, cell growth and migration. This brief review presents some information on MMPs' role in inflammatory, metabolic and cancer abnormalities related to the salivary glands, as well as MMP-related aspects that lead to the formation of human dentinal caries lesions. In oral diseases, the most relevant biological fluid commonly used for diagnosing periodontal diseases is saliva. In diseased patients with significantly higher levels of MMPs in their saliva than healthy people, most extracellular matrix components undergo digestion to lower molecular weight forms. Conventional treatment successfully reduces the levels of MMPs inhibits the progressive breakdown of gingival and periodontal ligament collagens. Beside inflammatory abnormalities like Sjögren's syndrome (SS), a large group of disorders is comprised of cancers, most of them involving the parotid gland (Adv Clin Exp Med 2016, 25, 2, 383-390).
\end{abstract}

Key words: dental caries, matrix metalloproteinases, tissue inhibitors of metalloproteinases, salivary glands, oral diseases.

\section{The Role of MMPs}

Matrix metalloproteinases (MMPs) belong to a family of structurally related zinc-dependent proteolytic enzymes that are known known to play a key role in the catabolic turnover of extracellular matrix (ECM) components. Research studies to date have indicated that MMPs regulate the activity of several non-ECM bioactive substrates, including growth factors, cytokines, chemokines and cell receptors, which determine the tissue microenvironment. These activities are implicated in a number of essential physiopathological processes [1-4].
MMPs are significant in the physiological processes of embryo development, wound healing and differentiation related to tissue remodeling. However, the overexpression of several MMPs is involved in tumor invasion, metastasis, disregulated angiogenesis, inflammation and even cell destruction $[1,5-9]$.

\section{MMP Subfamilies}

The first metalloproteinase was discovered in 1962 during a study of the ECM degradation re- 
sponsible for tadpole tail resorption [10-12]. Since then, the MMP family has grown to include at least 23 members in humans and 24 in mice. Some of them are not yet fully understood [10, 13]. Matrix metalloproteinases are considered members of the multigene metzincin family, which also includes transmembrane and secreted proteins called a disintegrin and metalloproteinases (ADAMs), a disintegrin and metalloproteinase with thrombospondin mofits (ADAMTSs), bone morphogenic protein 1/tolloid-like metalloproteinase (BMPI/ /TLLs) and meprins [14, 15]. The MMP family is divided into two groups based on their cellular localization (secreted or membrane-bound) or into six groups classified according to individual characteristics that are determined by the structure and substrate specificity: collagenases, gelatinases, stromelysins, matrilysins, membrane-type MMPs (MT-MMPs) and others. Collagenases primarily cleave interstitial collagen I, II, and III. Their catalytic domains are also needed for cleaving non-col- lagen and non-ECM elements. Gelatinases degrade gelatins, fibronectin and lamins. The third group of MMPs, stromelysins, have a similar structure to collagenases, but they do not cleave interstitial collagen. Matrilysins possess no hemopexin domain. MT-MMPs include four transmembrane members (MT1-, MT2-, MT3-, and MT5-MMP) and two glycosylphosphatidylinositol-annchored members (MT4-MMP and MT6-MMP). MT-MMPs are important enzymes involved in pericellular proteolysis and subsequent cell locomotion $[3,11,13$, $16,17]$. The properties of MMPs continue to make them an essential research topic in dermatology and periodontology (Table 1).

\section{The Structure of MMPs}

Different types of MMPs have a great deal in common (Fig. 1). They are characterized by a prodomain, catalytic domain, hemopexin do-

Collagenases

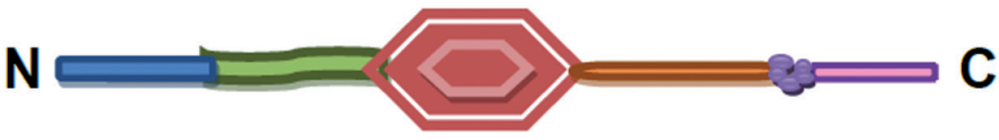

Stromelysines

Matrilysins

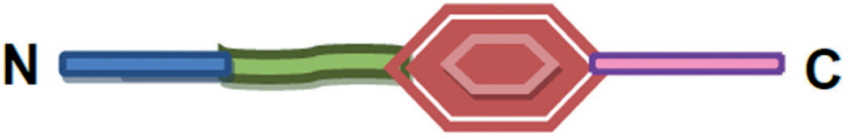

Membrane-type

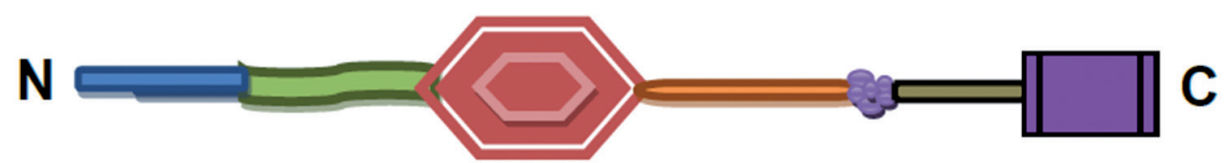

Gelatinases

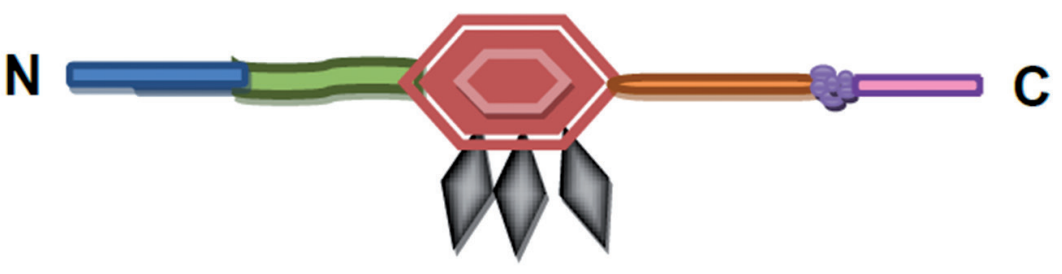

Signal sequence

$\mathbf{N}$

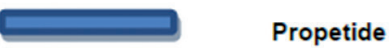

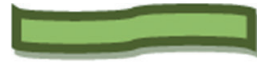

Hemopexin domain

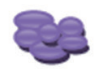

Cytosolic domain

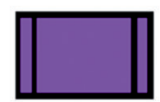

Fibronectin Repeat
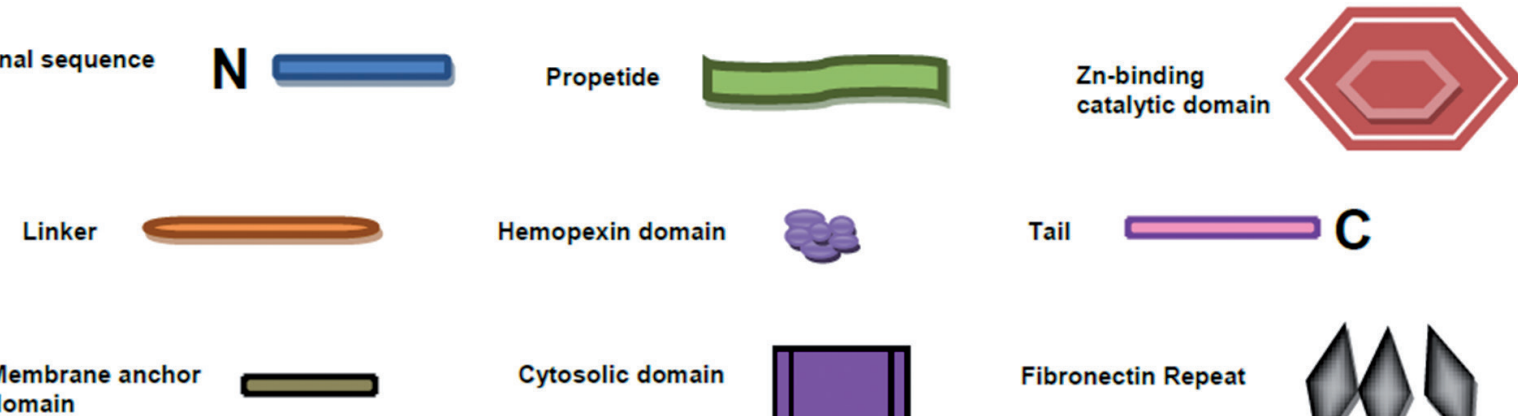

Tail

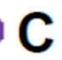

Fig. 1. Modular domain organization of different types of MMPs 
Table 1. Members of the MMP family and their classification

\begin{tabular}{|c|c|c|c|c|}
\hline Group & MMPs & Other names & Substrates & Possible method of analysis \\
\hline \multirow[t]{3}{*}{ Collagenases } & MMP-1 & collagenase-1 & $\begin{array}{l}\text { collagen: I, II, III, VII, VIII, X, aggre- } \\
\text { can, gelatin, MMP-2, -9 }\end{array}$ & zymography assay, immunoassay \\
\hline & MMP-8 & collagenase-2 & $\begin{array}{l}\text { collagen: I, II, III, V, VII, VIII, X, } \\
\text { aggrecan, elastin, fibronectin, gelatin, } \\
\text { laminin }\end{array}$ & $\begin{array}{l}\text { immunoassay, fluorimetric assay, } \\
\text { activity-based profiling assay }\end{array}$ \\
\hline & MMP-13 & collagenase-3 & $\begin{array}{l}\text { collagen: I, II, III, IV, aggrecan, gela- } \\
\text { tin }\end{array}$ & $\begin{array}{l}\text { fluorimetric assay, activity-based pro- } \\
\text { filing assay, zymography assay, fluo- } \\
\text { rimetric assay, phage-displayed assay, } \\
\text { multiple-enzyme/multiple-reagent } \\
\text { assay, activity-based profiling assay }\end{array}$ \\
\hline \multirow[t]{2}{*}{ Gelatinases } & MMP-2 & gelatinase-A & $\begin{array}{l}\text { collagen: I, II, III, IV, V, VII, X, XI, } \\
\text { aggrecan, elastin, fibronectin, gelatin, } \\
\text { laminin, proteo-glycan, MMP-9, -13 }\end{array}$ & $\begin{array}{l}\text { bioassay, zymography assay, immu- } \\
\text { noassay, fluorimetric assay, radio- } \\
\text { isotopic assay, multiple-enzyme/ } \\
\text { multiple-reagent assay }\end{array}$ \\
\hline & MMP-9 & gelatinase-B & $\begin{array}{l}\text { collagen: IV, V, VII, X, XIV, aggrecan, } \\
\text { elastin, fibronectin, gelatin }\end{array}$ & $\begin{array}{l}\text { bioassay, zymography assay, fluori- } \\
\text { metric assay, radioisotopic assay }\end{array}$ \\
\hline \multirow[t]{2}{*}{ Stromelysins } & MMP-3 & stromelysin-1 & $\begin{array}{l}\text { collagen: II, III, IV, IX, X, XI, aggre- } \\
\text { can, elastin, fibronectin, gelatin, lam- } \\
\text { inin, proteoglycan, MMP-7, }-8,-13\end{array}$ & $\begin{array}{l}\text { zymography assay, immunoassay, } \\
\text { fluorimetric assay, phage-displayed } \\
\text { assay }\end{array}$ \\
\hline & MMP-10 & stromelysin-2 & $\begin{array}{l}\text { collagen: III, IV, V, aggrecan, elastin, } \\
\text { fibronectin, gelatin, laminin, MMP-1, }-8\end{array}$ & $\begin{array}{l}\text { zymography assay, phage-displayed } \\
\text { assay, activity-based profiling assay }\end{array}$ \\
\hline \multirow[t]{2}{*}{ Matrilysins } & MMP-7 & matrilysin-1 & $\begin{array}{l}\text { collagen: IV, X, aggrecan, elastin, } \\
\text { fibronectin, gelatin, laminin, proteo- } \\
\text { glycan, MMP-1, -2, -9 }\end{array}$ & $\begin{array}{l}\text { zymography assay, immunoassay, } \\
\text { fluorimetric assay, phage-displayed } \\
\text { assay, activity-based profiling assay }\end{array}$ \\
\hline & MMP-26 & $\begin{array}{l}\text { Matrilysin-2, } \\
\text { endometase }\end{array}$ & $\begin{array}{l}\text { collagen: IV, gelatin, fibronectin, } \\
\text { gelatin }\end{array}$ & phage-displayed assay \\
\hline \multirow[t]{4}{*}{$\begin{array}{l}\text { Membrane- } \\
\text { type MMPs }\end{array}$} & MMP-14 & MT1-MMP & $\begin{array}{l}\text { collagen: I, II, III, aggrecan, elastin, } \\
\text { fibronectin, gelatin, laminin, MMP-2, } \\
-13\end{array}$ & \multirow[t]{4}{*}{ phage-displayed assay } \\
\hline & MMP-15 & MT2-MMP & $\begin{array}{l}\text { collagen: I, fibronectin, gelatin, lam- } \\
\text { inin, MMP-2 }\end{array}$ & \\
\hline & MMP-16 & MT3-MMP & collagen: I, MMP-2 & \\
\hline & MMP-24 & MT5-MMP & fibrin, gelatin & \\
\hline \multirow[t]{8}{*}{ Other MMPs } & MMP-11 & stromelysin-3 & $\begin{array}{l}\text { does not cleave collagen, aggrecan, } \\
\text { fibronectin, laminin }\end{array}$ & \multirow[t]{8}{*}{$\begin{array}{l}\text { activity-based profiling assay, immu- } \\
\text { noassay }\end{array}$} \\
\hline & MMP-12 & $\begin{array}{l}\text { metalloelas- } \\
\text { tase }\end{array}$ & $\begin{array}{l}\text { collagen: IV, elastin, fibronectin, gela- } \\
\text { tin, laminin }\end{array}$ & \\
\hline & MMP-19 & RASI-1 & $\begin{array}{l}\text { collagen: IV, fibronectin, aggrecan, } \\
\text { COMP, laminin, gelatin }\end{array}$ & \\
\hline & MMP-20 & enamelysin & $\begin{array}{l}\text { collagen: } \mathrm{V} \text {, aggrecan, amelogenin, } \\
\text { COMP }\end{array}$ & \\
\hline & MMP-21 & - & a1-anti-trypsin & \\
\hline & MMP-23 & CA-MMP & unknown & \\
\hline & MMP-25 & $\begin{array}{l}\text { MT6-MMP, } \\
\text { leukolysin }\end{array}$ & $\begin{array}{l}\text { collagen: IV, gelatin, fibronectin, lam- } \\
\text { inin, fibrin }\end{array}$ & \\
\hline & MMP-28 & epilysin & unknown & \\
\hline
\end{tabular}


main and, at the end, a transmembrane domain, glycosylphosphatidylinositol anchor or cytoplasmic tail $[5,18,19]$.

The prodomain with the highly conserved sequence PRCXXPD is present in all MMPs. It includes cysteine residue binding the catalytic zinc ion in a catalytic domain, which allows the pro-MMP to be kept in latent form. MMP activation can occur both on the extracellular and intracellular level: When the N-terminal inhibitory prodomain is eliminated, the catalytic position of the emerging enzyme becomes released and exposed. The subsequent domain is the catalytic one, which has the ability to degrade proteins because it contains the well-conserved zinc-binding motif HEXXHXXGXXH. In gelatinases, the catalytic domain contains fibronectin type II, which modulates protein interactions that are essential in substrate recognition. A proline-rich hinge region makes a connection between the catalytic domain and the following hemopexin domain. The hemopexin domain enables additional protein-protein interactions with substrates and with naturally occurring inhibitors. After the hemopexin domain, a transmembrane domain, glycosylphosphatidylinositol anchor or cytoplasmatic tail may be localized $[1,11,12,14,18,21-22]$.

\section{The Regulation of MMPs}

It is well known that enzymes are produced and secreted in an inert, latent form and are then activated in an intercellular or extracellular environment [23]. Most MMPs are synthesized and secreted as inactive proenzymes or zymogens (pro-MMP) that may be secreted or bound to the membrane, which results in their processing an activation, and their substrates may be partially degraded. The regulation of MMP expression must be strictly controlled in the tissues [23-25]. This takes place on a few levels:

- on the level of altering gene expression in patients with a genetic predispositions [26];

- on the level of transcription by cytokines (IL-1, TNF), hormones (parathormone, PTH) and bacteria products (LPS);

- on the level of enzyme sequestration to intracellular bubbles;

- on the level proenzyme activation (metal ions, oxidative stress, detergents, other proteolytic enzymem, plasmin);

- on the level of substrate specificity;

- through the $\mathrm{pH}$ of the environment;

- through tissue inhibitors of metalloproteinases (TIMPs) and serine protease inhibitors (serpins) [27].
The localization, activation and activity of MMPs are controlled by their interactions with other metalloproteinases, proteoglycan core proteins and/or their glycosaminoglycan chains [28]. The expression of MMPs is also influenced by numerous factors, e.g. the transformation of cells, hormones (depending on the cell type), some cytokines (such as IL-1 or IL-6), or growth factors (such as epidermal growth factor [EGF] or transforming growth factor-beta [TGF- $\beta$ ]) [29].

The precise control of the proteolytic activities of MMPs occurs via activation of their precursors as well as inhibition of endogenous inhibitor proteins, a-macroglobulin (a plasma protein which operates as a general proteinase inhibitor) and tissue inhibitors of metalloproteinases (TIMPs) [24].

As Brew and Nagase [30] wrote: "The human genome contains four paralogous genes encoding TIMPs 1 to 4". All four proteins in the TIMP family (TIMPs 1 through 4) are characterized by a largely similar structure [31]. It is worth noticing that TIMPs were initially characterized as inhibitors of MMPs, but later research has shown that they have a wider range of activities; it is now known now that they also inhibit some of the disintegrin-metalloproteinases, ADAMs and ADAMTSs [30, 31]. TIMPs bind and inhibit MMP activity at molar stechiometric proportion of $1: 1$. This is accomplished through a special structure comprised of 184 to 194 aminoacids that create an $\mathrm{N}$-domain responsible for the inhibition of MMP catalytic activity, and a C-subdomain that mediates interactions with the hemopexin domain of pro-MMPs $[32,33]$. TIMPs do not form covalent bonds with MMPs, nor are they cleaved by these enzymes, but they form tight complexes inhibiting the proteolytic activity of MMPs [33].

A disruption of the balance between the concentration of active metalloproteinases and their inhibitors may lead to pathological changes associated with uncontrolled ECM turnover, tissue remodeling, inflammatory response, cell growth and migration $[3,9,30]$. Additionally, the impact of TIMPs is fundamental to the homeostasis of the ECM, because of TIMPs' ability to control the interaction of cells via adhesion and signaling molecules such as growth factors. The significance of TIMPs as signaling molecules in their own right is only just beginning to be reported $[9,33]$.

\section{Methods}

Many studies have focused on the role of MMPs in biological processes and their involvement in diseases; as a consequence, several assay systems have been developed, including 1) bioassay, 
2) zymography assay, 3) immunoassay, 4) fluorimetric assay, 5) radioisotopic assay, 6) phage-displayed assay, 7) multiple-enzyme/multiple-reagent assay and 8) activity-based profiling assay.

Examining MMP activity is significant in the diagnosis and therapy of diseases associated with MMPs - i.e., illnesses of the salivary glands and skin [34].

\section{Salivary Glands}

Saliva contains a wide range of substances used in the clinical diagnosis of patients with oral and systemic diseases. Many medical researchers devote a great deal of time to finding a universal diagnostic tool that is easily collected and stored, and that can reveal hidden fatal threats before the disease becomes complicated. That is why saliva is gaining popularity as a source of data. It is regarded as a valuable biomarker providing information about oral and systemic human health $[35,36]$.

Saliva is commonly used for the diagnosis of periodontal diseases. The serum and salivary molecules contain immunoglobulins, enzymes, bacteria or bacterial products, volatile compounds and phenotypic markers [35]. The prevalent matrix metalloproteinases (MMP-2, -8, -9 and -13) are produced by polymorphonuclear leukocytes or osteoclasts, and interfere in local bone metabolism as well as being involved in the destruction of connective tissues. Periodontitis patients have significantly higher levels of these enzymes than healthy people. Most extracellular matrix components undergo digestion to lower molecular weight forms. Conventional periodontal treatment successfully reduces the MMP levels and inhibits the progressive breakdown of gingival and periodontal ligament collagens $[35,37,38]$.

Diabetes mellitus (DM), a metabolic disorder, can cause dysfunction of polymorphonuclear leukocytes, changes in vascularity, collagen alternations, synthesis of glycosaminoglycan and disregulation of cytokine production. Equally important is the generation of advanced glycation end products (AGEs) and the production of MMP-8 and -9 . All these elements combine to lead to periodontal tissue destruction [39].

The secretion of saliva is associated with presence of the major and minor salivary glands. $\mathrm{Hu}-$ mans (and mice) have three pairs of glands: the parotid glands (which are the largest), the sublingual glands and the submandibular macroscopic glands [40]. Sometimes a systemic autoimmune disease called Sjögren's syndrome (SS) attacks and damages the exocrine glands, which causes a loss of salivary and lachrymal secretion [41]. The eti- ology remains unknown, but immunological hyperactivity of anti-Ro and anti-La autoantibodies plays a primary role in the pathogenesis of this illness. Additionally, in the inflammatory process, aggregations of lymphocytes are initially periductal, but then become panlobular $[41,42]$. Immunoglobulin $\mathrm{G}$ (IgG) stimulates the production of IL-1b, PGE2, MMP-3 and MMP-9. MMP-3 (stromelysin-1) is able to degrade proteoglycans, some types of collagen, laminin, fibronectin, gelatin and elastin. It also activates other members of the MMP family, such as MMP-1 and MMP-9, increasing the destructive effect on ECM components [41-43]. The implication of metalloproteinases, including MMP-2 and -9 , has been proved in the nonobese diabetic (NOD) mouse model of Sjögren's syndrome that is frequently used as a spontaneous animal model of this disorder [44].

Cancers comprise another large group of disorders related to the salivary glands. Approximately $70-80 \%$ of them appear in the parotid glands. Among salivary gland neoplasms, 31 types of malignant salivary gland tumors have been distinguished, including synchronous neoplasms and metachronous neoplasms [45], salivary adenoid and cystic carcinomas, as well as benign neoplasms like salivary duct tumors [32].

\section{MMPs in Caries}

To provide a better understanding of the role of MMP activity in the oral environment, it is important to mention the formation of human dentinal caries lesions. Sorsa et al. demonstrated the contribution of both pro- and active forms of MMP-8, -2 and -9 [47]. After the demineralization of dentin by bacterial acids, enzymes contained in plaque and saliva and produced by odontoblasts break down the dentine matrix, consisting of collagen type I and small amounts of collagen type V. Non-collagenous proteins, including dentine matrix protein I, osteopontin and dentine sialoprotein, have also been suggested as activators of MMP pro-forms taking part in dentin matrix degradation $[47,48]$.

\section{The Future of Research into MMPs and Their Inhibitors}

The story of the MMP family in oral disorders is far from complete. Knowing basic MMP functions in the pathology of diseases, researchers are focusing on the post-translational regulation of MMP activity in order to identify the 
Table 2. Matrix metalloproteinases and tumor progression

\begin{tabular}{|l|l|}
\hline $\begin{array}{l}\text { MMPs accelerate } \begin{array}{l}\text { tumor progression } \\
\text { on the levels of: }\end{array} \\
\text { the result of several mechanisms that are a response to inactivating tumor suppressor genes or acti- } \\
\text { vating oncogenes. Proteolytic MMPs are able to release the bioactive molecules important in further } \\
\text { biochemical processes. Thus, they can mediate in the activation of anti-apoptotic and growth factors } \\
\text { or breakdown of cell-cell and cell-ECM constraints [32]. }\end{array}$ \\
\cline { 2 - 3 } & $\begin{array}{l}\text { 2. Angiogenesis. The pathological process of new blood vessel formation is closely regulated by } \\
\text { a complex of factors similar to that occurring in physiologic angiogenesis [46]. MMPs may regulate } \\
\text { the bioaccessibility of vascular endothelial growth factor (VEGF) and the division of matrix-bound } \\
\text { VEGF. Furthermore, they can change the balance between growth signals and growth-inhibiting } \\
\text { signals by activating the receptor of epidermal growth factor (EGF) and modulating the transforming } \\
\text { growth factor- } \beta \text { (TGF- } \beta \text { ) pathway. Many MMPs regulate the induction of apoptosis that is associated } \\
\text { with cleavage of Fas ligand, control inflammatory response, participate in the creation of metastatic } \\
\text { niches and influence the invasive processes [9]. }\end{array}$ \\
& $\begin{array}{l}\text { 3. Invasion and metastasis. The overexpression of metalloproteinases can occur both on the invasive } \\
\text { front and in the early stages of tumor progression. However, occurrence in the former case is much } \\
\text { more typical. In tumor cell invasion the most important mechanism is the breakdown of connective } \\
\text { tissue barriers. Tumors need MMPs to interact with the basement membrane and the extracellular } \\
\text { matrix. Cancer spreads by invasion of healthy tissue in three steps: attachment to the matrix, local } \\
\text { dissolution of the matrix by tumor cell-associated proteinases, and migration. Some metallopro- } \\
\text { teinases are produced by tumor cells but many of them are secreted in response to growth factors, } \\
\text { cytokines and chemokines. Carcinogenesis culminates in metastasis, leading to local expansion and } \\
\text { then successful colonization to distant organs, which is an often-fatal characteristic of malignant } \\
\text { tumors [8, 9, 25]. }\end{array}$ \\
\hline
\end{tabular}

macromolecular interactions of enzymes with specific compartments in the extracellular or intracellular environments, or with the cell surface. These interactions might accumulate the enzymes close to or on target substrates, which can result in activation of inactive pro-enzymes and cause abnormalities related to the salivary glands and the formation of human dentinal caries lesions. Enzyme activity should be regulated by the inhibition or prevention of the processing of a specific substrate. This information may provide clues about the synthesis of specific new MMP-inhibition targets for novel drugs to treat oral diseases, hopefully with fewer side effects than inhibitors currently available [28]. Further development of diagnostic techniques may allow researchers to discover advanced chair-side tests or mouth-rinse screening tests for monitoring periodontitis and peri-implantitis [47]. Using sali- va as a basic biological fluid in diagnosis, clinical trials can detect oral pathological changes in salivary proteins, which are related to excessive MMP expression [49]. Although there is large amount of evidence implicating various MMPs in oral diseases, MMP inhibitors are still problematic - especially in cancers. The role of MMPs in oral cancers still needs to be studied to find the proper combination of MMP inhibitors or their activators [47]. Many clinical tests have failed because of insufficient efficacy and undesirable side effects. Besides, in some disease models, one MMP brings about desired effects while another causes disease symptoms, and inhibiting both of them produces a complicated spectrum of results. Still, it is certain that the more medical research is done to examine the complexities of oral illness, the better the prospects will be for patients' recovery [14].

\section{References}

[1] Roy R, Yan GJ, Moses MA: Matrix metalloproteinases as novel biomarkers and potential therapeutic targets in human cancer. J Clin Oncol 2009, 27, 5287-5297.

[2] Shiomi T1, Lemaître V, D’Armiento J, Okada Y: Matrix metalloproteinases, a disintegrin and metalloproteinases, and a disintegrin and metalloproteinases with thrombospondin motifs in non-neoplastic diseases. Pathol Int 2010, 60, 477-496.

[3] Raffetto JD1, Khalil RA: Matrix metalloproteinases and their inhibitors in vascular remodeling and vascular disease. Biochem Pharmacol 2008, 75, 346-359.

[4] Kessenbrock K, Plaks V, Werb Z: Matrix metalloproteinases: regulators of the tumor microenvironment. Cell 2010, 141, 52-67.

[5] Sela-Passwell N, Rosenblum G, Shoham T, Sagi I: Structural and functional bases for allosteric control of MMP activities: can it pave the path for selective inhibition? Biochim Biophys Acta 2010, 1803, 29-38. 
[6] Manicone MA, McGuire JK: Matrix metalloproteinases as modulators of inflammation. Semin Cell Dev Biol 2008, 19, 34-41.

[7] Nan H, Niu T, Hunter DJ, Han J: Missense Polymorphisms in Matrix Metalloproteinase Genes and Skin Cancer Risk. Cancer Epidemiol Biomarkers Prev 2008, 17, 3551-3557.

[8] Gialeli C, Theocharis AD, Karamanos NK: Roles of matrix metalloproteinases in cancer progression and their pharmacological targeting. FEBS J 2011, 278, 16-27.

[9] Herszényi L, Hritz I, Lakatos G, Varga MZ, Tulassay Z: The behavior of matrix metalloproteinases and their inhibitors in colorectal cancer. Int J Mol Sci 2012, 13, 13240-13263.

[10] Chen Q, Jin M, Yang F Zhu J, Xiao Q, Zhang L: Matrix Metalloproteinases: Inflammatory Regulators of Cell Behaviors in Vascular Formation and Remodeling. Mediators Inflamm 2013, Article ID 928315, 14 pages. http:// dx.doi.org/10.1155/2013/928315.

[11] Benjamin MM, Khalil RA: Matrix metalloproteinase inhibitors as investigative tools in the pathogenesis and management of vascular disease. EXS 2012, 103, 209-279.

[12] Tallant C, Marrero A, Gomis-Rüth FX: Matrix metalloproteinases: Fold and function of their catalytic domains. Biochim Biophys Acta 2010, 1803, 20-28.

[13] van Hinsbergh VW, Koolwijk P: Endothelial sprouting and angiogenesis: Matrix metalloproteinases in the lead. Cardiovasc Res 2008, 78, 203-212.

[14] Jackson BC, Nebert DW, Vasiliou V: Update of human and mouse matrix metalloproteinase families. Hum Genomics 2010, 4, 194-201.

[15] Edwards DR, Handsley MM, Pennington CJ: The ADAM metalloproteinases. Mol Aspects Med 2008, 29, $258-289$.

[16] Etique N, Verzeaux L, Dedieu S, Emonard H: LRP-1: A checkpoint for the extracellular matrix proteolysis. BioMed Res Int 2013, Article ID 152163, 7 pages. http://dx.doi.org/10.1155/2013/152163.

[17] Gingras D, Béliveau R: Emerging concepts in the regulation of membrane-type 1 matrix metalloproteinase activity. Biochim Biophys Acta 2010, 1803, 142-150.

[18] Kerkelä E, Saarialho-Kere U: Matrix metalloproteinases in tumor progression: Focus on basal and squamous cell skin cancer. Exp Dermatol 2003, 12, 109-125.

[19] Schlöndorff J, Blobel CP: Metalloprotease-disintegrins: modular proteins capable of promoting cell-cell interactions and triggering signals by protein-ectodomain shedding. J Cell Sci 1999, 112 (Pt 21), 3603-3617.

[20] Tocchi A, Parks WC: Functional interactions between matrix metalloproteinases and glycosaminoglycans. FEBS J 2013, 280, 2332-2341.

[21] Sternlicht MD, Werb Z: How matrix metalloproteinases regulate cell behavior. Annu Rev Cell Dev Biol 2001, 17, 463-516.

[22] Strongin AY: Proteolytic and non-proteolytic roles of membrane type-1 matrix metalloproteinase in malignancy. Biochim Biophys Acta 2010, 1803, 133-141.

[23] Yan C, Boyd DD: Regulation of matrix metalloproteinase gene expression. J Cell Physiol 2007, 211, 19-26.

[24] Lenglet S, Mach F, Montecucco F: Role of matrix metalloproteinase-8 in atherosclerosis. Mediators Inflamm 2013, 2013, 659282.

[25] Folgueras AR, Pendás AM, Sánchez LM, López-Otín C: Matrix metalloproteinases in cancer: From new functions to improved inhibition strategies. Int J Dev Biol 2004, 48, 411-424.

[26] Vo NV, Hartman RA, Yurube T, Jacobs LJ, Sowa GA, Kang JD: Expression and regulation of metalloproteinases and their inhibitors in intervertebral disc aging and degeneration. Spine J 2013, 13, 331-341.

[27] Dziankowska-Bartkowiak B, Waszczykowska A, Żebrowska A: The role of metalloproteinases and their inhibitors in the pathomechanism of skin diseases. Alerg Astma Immunol 2004, 9, 71-79.

[28] Hadler-Olsen E, Fadnes B, Sylte I: Regulation of matrix metalloproteinase activity in health and disease. FEBS J 2011, 278, 28-45.

[29] Philips N, Auler S, Hugo R, Gonzalez S: Beneficial regulation of matrix metalloproteinases for skin health. Enzyme Res 2011, 427285.

[30] Brew K, Nagase H: The tissue inhibitors of metalloproteinases (TIMPs): An ancient family with structural and functional diversity. Biochim Biophys Acta 2010, 1803, 55-71.

[31] Stetler-Stevenson WG: Tissue inhibitors of metalloproteinases in cell signaling: Metalloproteinase-independent biological activities. Sci Signal 2008, 1, re6. DOI: 10.1126/scisignal.127re6.

[32] Cruz-Munoz W, Khokha R: The role of tissue inhibitors of metalloproteinases in tumorigenesis and metastasis. Crit Rev Clin Lab Sci 2008, 45, 291-338.

[33] Murphy G: Tissue inhibitors of metalloproteinases. Genome Biol 2011, 12, 233.

[34] Cheng XC, Fang H, Xu WF: Advances in assays of matrix metalloproteinases (MMPs) and their inhibitors. J Enzyme Inhib Med Chem 2008, 23, 154-167.

[35] Patil PB, Patil BR: Saliva: A diagnostic biomarker of periodontal diseases. J Indian Soc Periodontol 2011, 15, $310-317$.

[36] Malamud D: Saliva as a diagnostic fluid. Dent Clin North Am 2011, 55, 159-178.

[37] Sodek J, Overall CM: Matrix metalloproteinases in periodontal tissue remodelling. Matrix Suppl 1992, 1, 352-362.

[38] Mäkelä M, Salo T, Uitto VJ: Matrix metalloproteinases (MMP-2 and MMP-9) of the oral cavity: Cellular origin and relationship to periodontal status. J Dent Res 1994, 73, 1397-1406.

[39] Costa PP, Trevisan GL, Macedo GO: Salivary interleukin-6, matrix metalloproteinase-8, and osteoprotegerin in patients with periodontitis and diabetes. J Periodontol 2010, 81, 384-391. 
[40] Amano O, Mizobe K, Bando Y: Anatomy and Histology of Rodent and Human Major Salivary Glands. Acta Histochem Cytochem 2012, 45, 241-250.

[41] Reina S, Passafaro D, Sterin-Borda L: Atorvastatin inhibits the inflammatory response caused by anti-M(3) peptide IgG in patients with primary Sjögren's syndrome. Inflammopharmacology 2012, 20, 267-275.

[42] Tincani A, Andreoli L, Cavazzana I, Doria A, Favero M, Fenini MG, Franceschini F, Lojacono A, Nascimbeni G, Santoro A, Semeraro F, Toniati P, Shoenfeld Y: Novel aspects of Sjögren's syndrome in 2012. BMC Med 2013, $11,93$.

[43] Molina C, Alliende C, Aguilera S: Basal lamina disorganisation of the acini and ducts of labial salivary glands from patients with Sjögren's syndrome: Association with mononuclear cell infiltration. Ann Rheum Dis 2006, 65, $178-183$.

[44] Wildenberg ME, van Helden-Meeuwsen CG, Drexhage HA: Altered fractalkine cleavage potentially promotes local inflammation in NOD salivary gland. Arthritis Res Ther 2008, 10, R6 9.

[45] Whitt JC, Schafer DR, Callihan MD: Multiple malignant salivary gland neoplasms: Mucoepidermoid carcinoma of palate and adenoid cystic carcinoma of floor of mouth. Head Neck Pathol 2008, 2, 41-48.

[46] Deryugina EI, Quigley JP: Pleiotropic roles of matrix metalloproteinases in tumor angiogenesis: Contrasting, overlapping and compensatory functions. Biochim Biophys Acta 2010, 1803, 103-120.

[47] Sorsa T, Tjäderhane L, Salo T: Matrix metalloproteinases (MMPs) in oral diseases. Oral Dis 2004, 10, 311-318.

[48] Shimada Y, Ichinose S, Sadr A, Burrow MF, Tagami J: Localization of matrix metalloproteinases (MMPs-2, 8, 9 and 20) in normal and carious dentine. Aust Dent J 2009, 54, 347-354.

\section{Address for correspondence:}

Mateusz Maciejczyk

Students' Scientific Group "Stomatological Biochemistry"

Department of Conservative Dentistry

Medical University of Bialystok

Waszyngtona $15 \mathrm{~A}$

15-422 Białystok

Poland

E-mail: mateusz.maciejczyk@umb.edu.pl

Conflict of interest: None declared

Received: 4.07.2014

Revised: 14.08.2014

Accepted: 28.10.2014 